\title{
Promoting Shariah Governance in Corporation: Special Reference to Shura
}

\author{
Hartinie Abd Aziz \\ Kolej Yayasan Pahang \\ Pahang, Malaysia
}

\author{
Zuhairah Ariff Abd Ghadas
Universiti Sultan Zainal Abidin
Terengganu, Malaysia
zuhairahariff@unisza.edu.my \\ Zuhairah Ariff Abd Ghadas
Universiti Sultan Zainal Abidin
Terengganu, Malaysia
zuhairahariff@unisza.edu.my \\ Zuhairah Ariff Abd Ghadas
Universiti Sultan Zainal Abidin
Terengganu, Malaysia
zuhairahariff@unisza.edu.my \\ Zuhairah Ariff Abd Ghadas
Universiti Sultan Zainal Abidin
Terengganu, Malaysia
zuhairahariff@unisza.edu.my
}

Nazri Ramli
International Islamic University Malaysia
Selangor, Malaysia

\begin{abstract}
Abstrak-Al-Shura or consultation is an instrument for reconstruction and reform, mentioned in the Qur'an and suggested in the practices of the Prophet and his Companions Muhammad (PBUH) Generally, it is a tool used by Muslim scholars and rulers or caliphs in arriving a decision or ruling on particular matters or issues relating to the affairs of Muslims. However, there is a little discussion on the applicability of shura in business matters. In developing the framework of shariah corporation, there are few aspects that need to be scrutinized such as legal personality, principle of limited liability, registration of a company and the like. Other than that, board's decision making is another important structure to be analyzed in order to ensure its operation is shariah-compliant. In normal process in the company, the decision making had been done without collectively. This article discusses the concept of shura in Islam and why it should be applied in companies to promote shariahcompliant practices; especially those which carries out Islamic businesses. In this respect, this paper aims to highlight the role of siyasah syari'yah in promoting the practices of shura in corporate structure.
\end{abstract}

Keywords-Promoting Shariah; governance; corporation; alshura

\section{INTRODUCTION}

In a corporate structure, there are two organs which have power to decide for the company, namely the members who decide via the general meeting and the board of directors who decide in the board of directors meeting. the power of management is mainly delegated to the board of directors via the company's articles of association. A company, having no physical personality, is not able to decide on its own. Under the Islamic law, the decision making structure is called Shura. Shura is an Arabic term which is derived from a verb, 'Shawara'. It is also related with a word 'Shara' (Shara Yashuru - Shawrun) which means "the exhibited, showed or displayed a thing [1] Technically, Shura is defined [2] as: the meeting over something or issue as to ensure every person to ask another from such meeting for opinion of the concerned issue and to deduce a result from. It is also defined as: mankind gathering towards concluding a truth by presenting some opinions of a problem so that they are guided to a resolution.

Shura is a process of the social participation in the opinion or the resolution and a scope for the responsible social relationships and it is a term referred as a way which is labeled by our sharia to ensure the ummah eases with it through the sharia's pure purposes in order to reach its objectives, whereas the capability and strength which ease it along with these purposes are the true belief (aqidah) and the sharia law. Thus shura is a consultation which comes within the thoughts of ummah and opinions of its individuals in the society, whereas the sharia which includes shura as among its values and principles, creates these thoughts, purifies it, and makes it as righteous [3].

Shura is exchange of opinions in one of the matters relating to an individual believe, group of believers or the ummah, over a process, method, rules and principles, to reach goals and purposes associated in all in order to find the truth, or what is said to be nearer to it as obedience and worship, and all these process, method, rules, principles, goals and purposes are rabbaniyyah (from the divine by Lord) fixed by way of Allah, thus shura becomes a perfect system which closely links with the way of Allah to become part and parcel and inseparable from it. This paper purpose to discusses the concept of Shura and how it could be applied by the board of directors in a Shari'ah-compliance corporation [4].

\section{METHOD}

This research used descriptive qualitative method. Used Shura concept to discusses how it could be applied by the board of directors in a shari'ah-compliance corporation.

\section{FINDINGS}

\section{Principles of Shura}

The application of shura is clearly stated in the Quran, in 
the Sunnah of the prophet Muhamamad s.aw and consensus of Islamic scholars:

\section{Al-Qur'an}

Two leading verses which highlighted shura are:

Surah Al-Shura, verse 38: "..And those who have responded to their lord and established prayer and whose affair is [determined by] consultation among themselves, and from what We have provided them, they spend.

Surah Ali Imran, verse 159: "So by mercy from Allah , [O Muhammad], you were lenient with them. And if you had been rude [in speech] and harsh in heart, they would have disbanded from about you. So pardon them and ask forgiveness for them and consult them in the matter. And when you have decided, then rely upon Allah. Indeed, Allah loves those who rely [upon Him.

From these two verses, Qur'an highlighted the importance of shura as a mechanism of decision making in Islam. Among the lessons emphasized by Surah Al-Shura [3], verse 38 are:

Revelation of this verse is in Mecca before the hijrah and the establishment of the Islamic State, highlighted that shura is among the special attributes for the Muslims as the basis of social education for the individuals and its practice is obligatory among the Muslim in all circumstances even though the political system, the government or the State have not being established.

Shura is mentioned as the third attribute of the muslim community after the faith and prayers. This indicates that shura is regarded as a very important religious obligation (ibadah). Shura is also mentioned before the act of infaq which indicates that it is the basis of proprietary and economic relationships.

This verse is directed to all groups of people and not confined to the rulers only. Thus it shows that the ummah is obligated to practice shura and it is an collective responsibility of all individuals in the community.

The confirmation of shura as a principle to form the group does not render it to become a state or a political system; rather it is an exchange of the opinion and the positive participation of all members of the community.

Among the lessons emphasized by Surah Al-Shura [3], verse 38 are:
This verse was revealed in Medina after the establishment of the Islamic state. It was addressed to the prophet Muhammad s.a.w whom Allah chose to deliver the message of Islam, and who receives the divine commands through revelation of the Qur'anic (divine), Although there was no need for him to practice shura, Allah wants him to be a good example and requested the prophet Muhammad s.a.w to practice shura so that it will be an obligatory sunah,

The verse was revealed after the battle of uhud. All scholars unanimously agreed that the prophet pbuh had consulted one matter with the companions before the battle, whereas his opinion was that the Muslims should not go outside medina and remain there in order to give them advantage to confront the enemies easy. However, majority of the companions wanted to confront the enemy outside Medina until their survival in medina cannot be explained that he fears with facing the enemy. Then the prophet chose the opinion of the majority. While the result of the battle was worse over the muslims, people were afraid and thought that such thing became the reason the prophet departed from the consultation and the reason that he was not bound with their opinion. Thus this verse comes to remove such doubt in that He was obliged to pardon His ummah's majority of what occurred among them and to continue practicing the shura and bound by it. Since the verse is express and binding, this means that shura is obligatory and binding until if there is a possibility that the opinion of majority is wrong and harmful, because the harm resulting from the mistake done by the majority is lesser than the harm resulting from abandoning the shura and the tyranny of rulers in having the opinion without being bound by the opinion of all people and the majority.

This verse is not only the basis of obligation of the prophet to conduct shura but it covers the obligation of all generations which come afterwards to conduct shura as a sunnah in a sense that it is a quranic principle with express text, and it is the basis of all system in Islam whether such system relates to political, social, economic system and the like.

\section{Sunnah Of The Prophet Muhammad s.a.w}

Referring to bibliography of the prophet Muhammad s.a.w, it is clear that he had practiced shura in deciding most issues of the Muslim:

Abu Hurairah reported that: I never saw anyone consult his companions more often than the Messenger of Allah (Sunan Al-Tirmidzi \} 
It was reported by Abdul Rahman ibn Ghanam that the Prophet says to Abu Bakr and Umar: If you two are agree upon an opinion I would not oppose you [2]

Regarding the prisoners of the Battle of Badr, this was the first ever battle of the Muslims, and so the Prophet consulted his Companions over this issue of what to do with these prisoners. Abu Bakr advised the Prophet to pardon them and accept ransom on their behalf (in order to free them). 'Umar expressed that the disbelievers should be killed, and each one by his own relative (among the Muslims) (Sharh Sahih Muslim).

It was reported by $\mathrm{Al}-\mathrm{Hasan} \mathrm{Al}-\mathrm{Basri}$ that the prophet consulted with the companions until the woman then when she gave her opinion on something, He takes it [2]..

It was reported by Umar that the prophet says: "Verily Allah will not make my community -- or Muhammad's community -- agree on error, and Allah's hand is with the largest congregate [3]

It is narrated that the prophet used to say: "My community shall never agree upon misguidance, therefore, if you see divergences, you must follow the greater mass or larger group [3]

\section{The Consensus Of Companions}

All Muslims in all centuries unanimously agree that shura is obligatory. The first political practice done by the companions is when the day of shura occurred in Saqifah the tribe of Saa'dah to elect the leader of the Islamic state. Then the shura continued as a clear sign for administrative system in all periods of the caliphs. Among others are [2]:

The consultation of Abu Bakr with other companions on the issue of apostasy who refused to pay zakat to the State.

Abu Bakar consulted the ummah on who will be appointed as the next caliph after him. Then he said: O people, verily I had already made a promise, do you agree on that promise? Ali Ibn Abi Talib replied: we do not agree until such caliph is Umar.

Al-Bukhari said that: the ruler after the death of the prophet had consulted the trustees from the scholars in permissible matters in taking the easiest manner, when they found it in the Book or the Sunnah, they did not look into other things in order to follow the prophet. Thus whenever Abu Bakr faced an issue, he would look into Quran for solution, if he did not find the solution there, he would search for the prophet's action in that matter. If he did not find anything there, he would consult the prominent and pious sahabah, then he would follow the collective opinion.

During the time of Umar, he was the pioneer of the electoral shura concept. He was the first to officially form a council for the explicit purpose of conducting a process of selection of the next caliph after him. He appointed six members: Uthman ibn A'ffan, Ali ibn Abi Talib, Talha ibn U'baidillah, Sa'd ib Abi Waqqas, Abdul Rahman ibn A'uf, and Az-Zubay ibn Al-A'wwam. He instructed them to choose among themselves the one whom they agreed was most suited to hold the position.

Uthman said the following in his first address: Listen! I am a follower and not a discoverer of new ways. Know you all! I pledge three things after the following Quran and Sunnah. I will follow all decisions you have adopted by mutual agreement before me. I will find new ways only after consulting everyone, in the matters not decided

\section{Siyasah Syariah}

Literally, siyasah shariyyah means a shariah-oriented public policy, or government in accordance with the Shariah. Meanwhile, fuqaha' define siyasah shar'iyyah as decision and policy measure taken by the imam and the 'ulu al-amr on matters for which no specific ruling could be found in the sharia[5]. Ibn Qayyim mentioned the words of Ibn 'Aqil, "Siyasah is any measure which actually brings the people closest to beneficence (salah) and furthest away from corruption (fasad) partakes in just siyasah even if it has not been approved by the prophet saw nor regulated by divine revelation [6].

Interpreted siyasah shar'iyyah as a broad doctrine of Islamic law which authorizes the ruler to determine the manner in which the Sharia should be administered [5]. Likewise, [7] stated that siyasah shar'iyyah is administration of public affairs in an Islamic policy with the aim of realizing the interest of, and preventing harm to, the community in harmony with the general principles of the Sharia even if it disagrees with the particular rulings of the mujtahidin. There are some examples of the implementation of siyasah shar'iyyah made by companions. Among them is the decision of Umar ibn Khattab to stop the distribution of zakat to muallaf is made based on the siyasah shar'iyyah that Allah has exalted Islam and it is no longer in need of muallaf favor. Besides, the elimination of muallaf as mustahiq may strengthen the distribution of zakat to the other mustahiq. Based on the aforementioned case, where the Caliph has employed siyasah shar'iyyah as a tool to determine the ruling or to solve problems [8]. 


\section{DISCUSSION}

To apply the concept of shura in corporate structure, it is important for the company to emphasized on the importance of the concept of siyasah shariyyah, via a policy introduced by the Board of directors to ensure control of the business affairs and at the same valuing views of members of the company. The concept of siasah syariyyah can be used as the tool to solve problems by teamwork and participation of members of the company; and not merely confined to the board of directors The involvement of the directors are mainly related to business affairs, i.e. the scope of fiqh muamalat which becomes a part of the conducts of mukallaf.

In companies which carried on Islamic businesses, it is invigorated to apply shura in the decision making process of the company. This could only be done if the board of directors embeds the principles of Siyasah syariah so that it will make it compulsory for the company to implement Shura in the decision making process.

\section{CONCLUSION}

Shura in Islam is not only a political theory or principle for the administrative constitution which is viewed by some jurists, but it is a legal basis to the system of society, which is bound by the rights of human, authority of the ummah and social responsibility. Thus, the application of shura is not confined to Islamic administrative system only but also relates to rights of human being and his basic freedom to decide for his benefit and benefit of all ummah. It is highly encouraged for the companies to introduce shura policy as it promotes good decision making structure via team work and collective responsibilities.

\section{REFERENCES}

[1] Nor Razinah Mohd Zain, Zulkarnain, I. F., \& Hassan, P. D. R. (2015). Shari'ah Corporate Governance Structure of Malaysian Islamic Banking and Finance: The Traces of Shura. Journal of Islamic Banking and Finance, Vol. 3(1), 28.

[2] Dr. Mahmud Al-Khalidi. (1986). Nidzham Al-Shura Fi Al-Islam (1st Editio). Oman, Jordan: Maktabah AlRisalah Al-Hadithah.

[3] Al-Shawi, D. T. (1990). Figh Al-Shura wa Al-Istisharah. Al-Mansurah: Dar Al-Wafa' Li Al-Tibaa'h wa Li AlNashr wa Al-Tawzi'.
[4] Jaber, P. D. (2009). Al-Shura wa Ahlu Al-Hilli wa AlA'qdi Fi Al-Siyasah Al-Shariyyah (1st Editio). AlAkademiyyun Li Al-Nashr wa Al-Tauzi'.

[5] Kamali, M. H. (1989). Siyasah Shariyyah or Policies of the Islamic Government. The American Journal of Islamic Social Sciences, 6(1), 61.

[6] Sa'adah, D. A. A. (2010). An-Nadzariyyah Al-A'amah Lilmasuliyyah Al-Qadhaiyyah Fi At-Tasyri' Al-Islami (1st Editio). Oman Jordan: Dirasah Ta'siliyyah Fi AlFiqhi Al-Islami Wa As-Siyasah As-Syariyyah, Darul AtThaqafah Lin-Nashri Wa At-Tauzi'.

[7] Khallaf, A. W. (2003). Siasah Syar'iyyah Dalam Pemerintahan Islam,. KualaLumpur: Al-Hidayah Publishers.

[8] Bedjo Santoso. (n.d.). Money in Islam: The Siyasah Shari'yyah' Perspective and Implementation Strategy,. Tazkia Islamic Finance and Business Review, 7.2, 214215. 